\title{
ANALÝZA SLOVENSKEJ A ČESKEJ DABINGOVEJ VERZIE AUDIOVIZUÁLNEHO DIELA QU'EST-CE QU'ON A FAIT AU BON DIEU?
}

\author{
JANA UKUŠOVÁ
}

\begin{abstract}
Analysis of Slovak and Czech Dubbed Version of the Audiovisual Work Serial (Bad) Weddings

The paper deals with a comparative analysis of Slovak and Czech language versions of the contemporary French movie Qu'est-ce qu'on a fait au Bon Dieu? (in Slovak: Čo sme komu urobili?, in Czech: Co jsme komu udělali?). The analysis focuses on the expressive level of the given audiovisual work. The aim is to examine the adequacy and functionality of information transfer when translating expressive lexical units, colloquial vocabulary and culturally conditioned units. The process of analysis is based on our own experience as a viewer (the knowledge of both the original and translated versions of the audiovisual work) and subsequent interpretation of the adopted translation solutions. These are categorized from the viewpoint of changes at the expressive level that necessarily occur in the translation process, and in case of a negative transfer, we present our own translation solutions.
\end{abstract}

Keywords: audiovisual translation; comparative analysis; expression system; dubbing

\section{1. Úvod a metodologické východiská}

Materiálovú bázu, ktorú v príspevku podrobíme analýze, predstavuje súčasné audiovizuálne dielo francúzskej proveniencie Qu'est-ce qu’on a fait au Bon Dieu? ${ }^{1}$, ktoré malo vo Francúzsku premiéru v roku 2014. Z hladiska žánru možno dielo klasifikovat ako komédiu. Vo filme sa stretávame s rodinou Clauda a Marie Verneuillovcov, konzervatívnych francúzskych občanov, katolíkov, ktorých tri dcéry sa vydali za synov imigrantov (Araba, Žida, Číňana), pričom štvrtá, najmladšia dcéra si chce zobrat’ za muža černocha. Zápletka filmu je vybudovaná okolo procesu, ako sa rodičia snažia s vol'bou svojich dcér vyrovnat’ a utužit rodinné vztahy na pozadí aktuálnych otázok multikulturality, globalizácie, tolerancie, harmonickej koexistencie rôznych vierovyznaní, mentalít a kultúr, ale aj rasizmu.

1 Velký úspech filmu viedol tvorcov k nakrúteniu pokračovania s názvom Qu’est-ce qu’on a fait encore au Bon Dieu? Vo Francúzsku mala druhá čast premiéru 30. januára 2019. 
Za predmet našej analýzy sme si film zvolili najmä preto, že ponúka vela priestoru na komparatívnu analýzu významovo-výrazovej stránky (najmä expresívnych a hovorových výrazových jednotiek). V procese analýzy na základe interpretácie a komparatívnej analýzy hodnotíme a komentujeme prekladatelské riešenia v českom a slovenskom znení $s$ cielom určit, či pri preklade štylisticky príznakových jednotiek nedochádza k posunom. $\mathrm{V}$ analýze sa nezameriavame výlučne na lingvistickú rovinu vybraných lexikálnych jednotiek, ale vnímame ich na pozadí jednotlivých kultúr, ako aj štylistického úzu v audiovizuálnom preklade. Tento prístup považujeme za nevyhnutný na to, aby sme mohli lepšie pochopit a určit, či sú prekladatel'ské riešenia výsledkom zohladňovania noriem prijímajúcej (t. j. českej a slovenskej) jazykovej kultúry alebo či v preklade dochádza $\mathrm{k}$ negatívnym posunom.

Príspevok pozostáva z teoretickej a praktickej časti. V teoretickej časti vymedzujeme audiovizuálny preklad vzhladom na ostatné druhy prekladu, zameriavame sa na osobitné črty práce dabingového prekladatela a úpravcu a preberáme typológiu mikroštylistických posunov podla Antona Popoviča. Praktickú časț tvoria vybrané ukážky z francúzskeho, slovenského a českého znenia filmu, doplnené $\mathrm{v}$ každom prípade o krátky komentár. Takisto treba spomenút, že slovenský preklad analyzovaného diela vyhotovila slovenská dabingová herečka, prekladatel'ka a úpravkyňa Jasna Navrátilová a autorkou českého prekladu je prekladatelka, herečka, režisérka a úpravkyňa dialógov Veronika Bandyová.

\section{Audiovizuálny preklad ako osobitý typ prekladu}

J. Díaz-Cintas, jeden z významných zahraničných teoretikov i praktikov na poli audiovizuálneho prekladu, vymedzuje oblast' audiovizuálneho prekladu ako preklad produktov, v ktorom sa verbálna zložka doplńa na základe zložiek iného média (Díaz-Cintas Remael 2007: 13). V slovenskej teórii prekladu sa otázkam audiovizuálneho prekladu so zameraním na dabing venuje v najväčšej miere Lucia Paulínyová. Vo svojej najnovšej publikácii $Z$ papiera na obraz - Proces tvorby audiovizuálneho prekladu (2017) tvrdí, že $\mathrm{v}$ slovenskom kontexte doposial pomenovanie ani výklad pojmu, ktorým sa označuje audiovizuálny preklad, nemajú jednotný charakter. Paulínyová ponúka na pozadí slovenskej translatologickej tradície nasledovné vymedzenie audiovizuálneho prekladu: „preklad audiovizuálneho diela, založeného na obraze, zvuku a jazyku, pričom prekladatel'ský proces sa odvíja od všetkých troch zložiek“ (Paulínyová 2017: 20).

Typologicky možno audiovizuálny preklad členit na dve hlavné skupiny, a to preklad titulkov a dabingový preklad. Dabingový preklad nasledovne pozostáva z piatich podskupín, ktorými sú televízny dabingový preklad, filmový dabingový preklad, slepý dabingový preklad, preklad hovoreného komentára a preklad audiokomentára (ibid.: 26). Na základe uvedenej typológie možno nami analyzované dielo začlenit do kategórie filmového dabingového prekladu.

\section{1 Špecifiká práce dabingového prekladatela}

Paulínyová (2017: 60-73) sa podrobne zaoberá aj náplňou práce dabingového prekladatela ako pôvodcu audiovizuálneho diela v novom jazykovom znení. Jeho úlohou je 
zachovat’ pri preklade všetky aspekty umeleckého dialógu (na úrovni replík) a preniest’ ich významovo presne a prirodzene do cielového jazyka.

Paulínyová d’alej uvádza, že osobitost' práce dabingového prekladatela sa v niektorých bodoch prekrýva s prácou umeleckého prekladatela, ale dabingový preklad má aj svoje špecifiká, ktoré spočívajú, okrem iného, v týchto úlohách: práca s dvomi originálmi (s pôvodnou dialógovou listinou ${ }^{2}$ a audiovizuálnym originálom (tzv. „obraz“)), písaná tvorba určená na ústne podanie (výber vhodných lingvistických a štylistických ${ }^{3}$ prostriedkov), adekvátny, prirodzený a významovo presný preklad (dabingový preklad musí byt významovo presný, prekladatel' musí mat’ na pamäti, že s prekladom bude dalej pracovat dabingový úpravca), zachovanie charakteru postavy (rečový prejav postáv by mal byt $\mathrm{v}$ zhode $\mathrm{s}$ ich charakterom a sociálnym pozadím), zachovanie čistoty štýlu, uvádzanie poznámok prekladatel’a (prekladatel' svojimi poznámkami ulahčuje prácu dabingovému úpravcovi vo forme vysvetliviek týkajúcich sa výslovnosti, zložitých konštrukcií či výrazov s ciel'om predíst' ich nesprávnemu výkladu zo strany úpravcu), fonetický prepis cudzích názvov a mien a uvádzanie alternatívy (v prípade slovných hračiek, vtipov, prezývok a pod.) ${ }^{4}$ (ibid.)

\subsection{Dabingový prekladatel' vs. dabingový úpravca}

Už v predchádzajúcej časti sme viackrát spomenuli osobnost̉ dabingového úpravcu, ktorý je neodmyslitelnou súčastou procesu dabingového prekladu. Vztah medzi prácou dabingového prekladatel’a a úpravcu je velmi úzky a zároveň časovo vymedzený. Zahorák (2018: 54-60) uvádza, že dabingový úpravca d’alej pracuje s preloženou dialógovou listinou, t. j. robí zmeny, ktoré majú viest’ k čo najlepšej zhode na jazykovej aj mimojazykovej rovine. Jazyková zhoda medzi pôvodným a novým znením spočíva v ich kvantitatívnej (zhoda v dîžke replík a vo frázovaní), kvalitatívnej (zhoda v artikulácii hlások) a rytmickej zhode (zhoda v rytme vety), pričom mimojazyková zhoda sa realizuje na základe mimického, kinetického a gestikulačného súladu. Mimojazyková zhoda navyše nesmie byt vo významovom rozpore s jazykovou zhodou, ale má ju naopak doplňat'.

\section{Mikroštylistická rovina diela}

Aby sme mohli komentovat' a hodnotit’ zvolené prekladatel’ské riešenia štylisticky príznakových jednotiek v slovenskom a českom znení, považujeme za nutné teoreticky vymedzit’ rámec štylistických operácií, zmien a posunov, ku ktorým v procese prekladu nevyhnutne dochádza. Anton Popovič (1983) na margo posunu výrazových vlastností v preklade tvrdí, že na pozadí rozdielov medzi jazykovými, literárnymi a kultúrnymi kódmi sa preklad vzhladom na originál „musí posunút“ (Popovič 1983: 198). Preto štylistické

2 Na účel toho príspevku sa nám žial nepodarilo dostat k dialógovým listinám, preto sme text dekódovali na základe odposluchu, pričom v prípade francúzskeho znenia sme si pomáhali aj francúzskymi titulkami.

3 Vhodný výber štylistických prostriedkov sa javí ako klúčový aj z hladiska našej analýzy.

4 Posledné tri uvedené body sa nevztahujú priamo na našu analýzu, považovali sme však za vhodné zmienit sa o nich aspoň v krátkosti, kedže sme chceli podat komplexnejší obraz o úlohách, ktoré sú neoddelitelnou súčastou práce dabingového úpravcu. 
operácie znamenajú práve „vyhladávanie a zvažovanie primeranosti, únosnosti štylistických ekvivalentov nahradzujúcich príslušné výrazové vlastnosti originálu v preklade“ (ibid.: 189).

V praktickej časti nášho príspevku preto budeme skúmat', či sú zvolené štylistické operácie adekvátne a opodstatnené, t. j., či vyplývajú z odlišnosti francúzskeho a českého, resp. slovenského jazykového a kultúrneho kódu, alebo či ide o posuny, ktoré majú negatívny charakter. Na tento účel preberáme Popovičovu (1983) typológiu zmien na mikroštylistickej rovine (jazyková výstavba diela), z ktorej vychádza aj Gromová (2003: 65-68). V rámci tejto roviny môžeme rozlišovat tri pozície vzt’ahu medzi výrazovými vlastnostami originálu a prekladu. Výrazová zhoda predstavuje adekvátne obsiahnutie významového invariantu a realizuje sa bud' substitúciou (funkčnou náhradou) nepreložitel’ných prvkov alebo inverziou (funkčným premiestnením) výrazových prvkov na iné miesto v rámci prekladu. Výrazové zosilnenie znamená zdôrazňovanie výrazových vlastností originálu a prejavuje sa väčšou subjektívnostou a expresívnostou prekladového textu. Realizuje sa na základe výrazovej typizácie alebo individualizácie. Poslednou pozíciou tohto vztahu je výrazové zoslabenie a v praxi ide naopak o zoslabovanie výrazových vlastností originálu. Vedie k výrazovej nivelizácii (ochudobňovaniu o výrazové črty originálu v preklade) alebo až $\mathrm{k}$ ich úplnej strate v prekladovom texte.

Na tomto mieste by sme ešte chceli podotknút, že sa v rámci našej analýzy nebudeme venovat zvukovej rovine diela (intonácia, melódia, rýchlost̉ replík), gestám, ktoré sú sprievodnými prvkami reči, ani d’alším kontextovým prvkom. Uvedomujeme si však, že všetky uvedené prvky sa podielajú na finálnom vyznení repliky.

\subsection{K otázke štylistického rozvrstvenia českého a slovenského jazyka a jeho využitia v audiovizuálnom preklade}

Aj slovenský divák-nelingvista si pri sledovaní českých a slovenských dabingových verzií audiovizuálnych diel všimne, že české filmové/seriálové znenie sa tradične v prepojení na slovenskú verziu rovnakého cudzojazyčného audiovizuálneho diela vyznačuje väčšou expresívnostou, resp. väčším rozpätím výrazových prvkoch. Domnievame sa, že túto skutočnost' možno zdôvodňovat tým, že v slovenčine existuje skôr tendencia expresívne výrazy (slangové, hovorové, vulgárne) v audiovizuálnom preklade neutralizovat či zjemňovat', v češtine sa väčšia expresívnost’ dosahuje na základe používania tzv. obecnej češtiny. Pokial' je nám však známe, slovenčina v porovnaní s českým jazykom nedisponuje polohou jazyka, ktorá by predstavovala adekvátny ekvivalent k obecnej češtine. Okrem toho, spomínaná tendencia zjemňovania v rámci slovenských audiovizuálnych diel zatial' podla našich vedomostí nebola dostatočne teoreticky rozpracovaná. ${ }^{5}$

Na druhej strane, obecnú češtinu vymedzuje Štícha (2013) ako nespisovnú podobu českého jazyka, ktorá sa používa na celom území Čiech a na časti územia Moravy. Navyše dodáva, že je vel'mi tažké presne vymedzit hranicu medzi obecnou a hovorovou češtinou.

5 Istý náhlad do tejto problematiky môže poskytnút Zákon o vysielaní a retransmisii, no iba v tom prípade, ak ide o používanie vulgárnych výrazov. V \$20 (8) tohto zákona sa konkrétne zakazuje „šírenie správ, slovných výpovedí alebo obrazov, kde sa násilný obsah dostáva neopodstatnene do popredia“" ako súčast ochrany maloletých. $\mathrm{V} \S 19$ (1) a) sa zase upravuje ochrana ludskej dôstojnosti. 
Krčmová (2017) dodáva, že tradične sa obecná čeština chápe v zmysle jazyka hovorenej súkromnej, resp. poloverejnej komunikácie, ktorý je z regionálneho aj sociálneho hladiska málo príznakový.

Problematiku používania obecnej češtiny v audiovizuálnom preklade, konkrétne v titulkoch, rozpracoval Pošta (2013: 35-37). Tvrdí, že v českých titulkoch dochádza k miešaniu spisovnej (resp. písomnej) češtiny a češtiny obecnej, ktorú používa na bežnú komunikáciu väčšina obyvatel’ov Česka. Vždy je práve na prekladatelovi, aby v danom filme zvolil správny pomer spisovnosti a nespisovnosti. Pošta okrem toho dodáva, že česká dabingová verzia je v porovnaní s českými titulkami k rovnakému filmu tradične, vzhladom na častejšie používanie obecnej češtiny, menej spisovná.

$\mathrm{Na}$ základe uvedeného pracujeme v príspevku s predpokladom, že česká verzia analyzovaného filmu bude lepšie vystihovat príznakové štylistické jednotky a že v nej bude v porovnaní so slovenským znením dochádzat' k menšiemu výrazovému zoslabovaniu.

\subsection{Analýza vybraných ukážok českého a slovenského znenia}

$\mathrm{Na}$ tomto mieste pristúpime ku konfrontačno-komparatívnej analýze príznakových lexikálnych jednotiek. Analyzované ukážky sme vyberali z celej dĺžky filmu (stopáž: 97 min.) na základe výskytu príznakových jednotiek. Vzhladom na rozsah tohto príspevku doň nebolo možné zahrnút všetky pasáže filmu, ktoré obsahovali príznakové lexikálne prvky, preto sa sústredíme na vybrané časti. Pred každou analyzovanou ukážkou uvádzame časový údaj odkazujúci na jej umiestnenie vo filme.

Prvú skupinu vybraných prekladatel’ských riešení predstavujú príklady hovorovej a expresívnej lexiky, zatial' čo druhú skupinu analyzovaných jednotiek tvoria príznakové kultúrne lexémy. V závere praktickej časti sa stručne vyjadríme aj k nejasnostiam, resp. nepresnostiam na významovej rovine prekladového textu, ktoré môžu stažit jeho pochopenie pre slovenských a českých recipientov.

Ako sme už spomenuli, pre účely tohto článku sa nám nepodarilo získat originálnu a prekladovú dialógovú listinu, preto nemôžeme s určitostou konštatovat', či je dané prekladatel'ské riešenie výsledkom práce prekladatela, zásahu dabingového úpravcu, alebo či vzniklo až v neskoršej fáze dabingového procesu priamo pri realizácii v štúdiu. Naším cielom je však porovnat adekvátnost’ dabingového prekladu z lingvistického, resp. výrazového aspektu.

\subsubsection{Hovorová a expresívna lexika}

\section{1:05:57}

FR: Attend, ça va, deux secondes. C'est pas les jeux olympiques.

SK: Vydrž, nie sme na olympiáde.

CZ: Dej si voraz, nejsme na olympiádě.

Prvá vybraná ukážka hovorovej lexiky pochádza z rozhovoru medzi Charlesom a Rašidom, ktorých pri zápase v stolnom tenise vyrušia Chao s Davidom (na tomto mieste treba podotknút, že práve títo štyria švagrovia používajú vo filme rozmanité jazykové 
prostriedky vrátane hovorovej lexiky, slangu či vulgarizmov, preto rečový prejav do vel'kej miery dotvára charaktery ich postáv). Kedže Rašid v zápase prehráva, je za toto vyrušenie rád. Výraz attend, ça va, deux secondes sa vyznačuje istým stupňom hovorovosti (elidovanie častice ne, skrátený tvar cela - ça a použitie hovorového spojenia ça va).

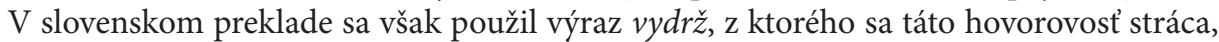
a text sa ochudobňuje. Vhodnejším riešením, ktoré by obsiahlo danú hovorovost' výrazu, by mohol byt' preklad s použitím častice ved' - ved' vydrž, čím by sa zároveň dosiahla aj väčšia kvantitatívna zhoda na úrovni repliky (nevieme však s istotou určit, či bol na skrátenie tejto repliky nejaký iný dôvod). České znenie na tomto mieste obsahuje až výrazové zosilnenie, pretože sa zvolil prostriedok obecnej češtiny - dát si voraz s expresívnejším nábojom, ktorý sa však zo situačného hladiska do repliky hodí. Z hladiska adekvátnejšieho zachovania výrazovej hodnoty by prichádzalo do úvahy aj riešenie Hele, počkej, nejsme přece na olympiádè.

\section{1:14:17}

FR: Kate Middleton peut aller se rhabiller.

SK: Kate Middletonová by zbledla závistou.

CZ: Kate Middletonovou strč́š do kapsy.

V tejto ukážke by sme radi poukázali na francúzsky hovorový výraz pouvoir aller se rhabiller, ktorý znamená nebyt' dostatočne dobrý v porovnaní s druhým resp. neobstát $v$ konkurencii. Vo filme je použitý počas scény, ked’ si Laura skúša svadobné šaty. Je tu prítomná alúzia na britskú královskú svadbu z roku 2011 a na šaty vojvodkyne Kate Middletonovej. V slovenskom preklade možno identifikovat’ nie úplne adekvátne prenesenie významu daného spojenia (zblednút závistou) a zároveň nivelizáciu hovorovosti francúzskeho výrazu. Autorka tejto repliky, Laurina sestra Isabelle, ňou chce poukázat' na skutočnost', že Laura v svadobných šatách vyzerá ovel’a, ovel’a krajšie ako samotná vojvodkyňa Kate. S cielom zachovat v preklade tento význam a zhodu na úrovni výrazu by sme navrhovali riešenie Kate Middletonová sa môže schovat'. V českom preklade sa zachováva výrazová zhoda použitím hovorového spojenia strčit’ někoho do kapsy.

\section{0:41:57}

FR: C'est passé comme une lettre à la poste.

SK: Dobre to dopadlo.

CZ: Šlo to jako po másle.

\section{0:25:30}

FR: T'avais promis de m’inviter à Paris ! J'attends toujours le billet.

Ma valise est prête depuis 1920.

SK: Slúbil si, že ma pozveš do Paríža, a stále nič. Už niekolko rokov som zbalená.

CZ: Slíbils mi výlet do Pařiže a pořád nic. Mám sbaleno už sto let.

V tretej a štvrtej uvedenej ukážke by sme chceli opät poukázat’ na istý stupeň výrazového zoslabovania príznakových francúzskych lexém v slovenskom preklade a ich adekvátnejší transfer v českom preklade. Domnievame sa, že nejde o postup, ktorý by 
mohol byt’ odôvodnený na základe výrazných odlišností v kultúrnom či jazykovom kóde, a slovenský ekvivalent nie je úplne adekvátny. V prvom prípade ide o spojenie passer comme une lettre à la poste = passer très facilement. Používa sa na označenie situácie, ked' niečo prebehne bez problémov, vel’mi lahko (t. j. ako v českom preklade - jako po másle). V slovenčine sa tento výraz zredukoval na neutrálny preklad dobre. Stráca sa tak nielen expresívnost' výrazu, ale aj istý humorný efekt a kontrast. Odkazuje sa totiž na rozhovor Laury s rodičmi ohladom jej vydaja, ktorý však vôbec nešiel podla jej predstáv, pretože im nedokázala povedat tú najhlavnejšiu vec - jej budúci manžel Charles má africké korene. Preklad Šlo to jako po másle tento kontrast adekvátne podčiarkuje.

V druhom prípade sa expresívnost’ vzt’ahuje na časový úsek depuis 1920 a zámerom je poukázat' na vel'kú túžbu Charlesovej sestry navštívit Paríž. V českom preklade má zbalené $u z ̌$ sto let, zatial' čo v slovenskom len niekol'ko rokov. V prepojení na francúzsky originál možno z hladiska výrazovej hodnoty opät považovat za adekvátnejší český preklad. Jedným z možných dôvodov použitia výrazu už niekol'ko rokov v slovenskom preklade by mohla byt’ snaha o predÍženie repliky, aby lepšie zodpovedala počtu slabík v originálnej replike či iný zásah v rámci dabingovej úpravy. Česká replika je totiž v porovnaní s francúzskou podstatne kratšia.

$\mathrm{Na}$ základe doteraz uvedených príkladov sa ukazuje tendencia, že v českom jazyku sa lepšie pracuje s príznakovými francúzskymi jednotkami a zároveň sa adekvátnejšie zachovávajú zodpovedajúce výrazové kvality, pokial' ide o ich expresivitu a hovorovost'. Vo filme sme zaznamenali aj prípady, ked’v českom znení nastalo na viacerých miestach výrazové zosilnenie, t. j. český preklad bol expresívnejší ako francúzsky originál. Na ilustráciu uvádzame nasledovné dva príklady.

$0: 15: 39$

FR: Ça n’a pas été simple. Mais maintenant ça se passe très bien.

SK: Nebolo to lahké, ale zvykli sme si.

CZ: Nebylo to snadné, ale už to klape.

$\mathrm{V}$ češtine nastáva v uvedenej ukážke výrazové zosilnenie v druhej časti repliky ça se passe très bien - už to klape. Uplatňuje sa expresívny hovorový výraz klapat (dobre fungovat'). Na prvý pohlad by sa mohlo zdat', že takýto rečový prejav je v rozpore s charakterom postavy, kedže ide o kňaza. Kňaz vo filme je však mladý, moderný človek (napríklad nakupuje liturgické oblečenie cez internet), a preto usudzujeme, že tento výraz neprotirečí jeho charakteru, ale naopak, vystihuje ho.

\section{0:12:34}

FR: Les Feujs' dans la finance, c'est terminé! C'est nous, maintenant, les Noich' qui avons le vent en poupe.

SK: Židia v bankách skončili. Lebo my sme teraz prevzali štafetu.

CZ: Židi a financiéri jsou dávno passé. Ted’ jsou na koni Čínani.

V tejto ukážke dochádza k výrazovému zosilneniu spojení c’est terminé - skončili / jsou dávno passé, ako aj nous avons le vent en poupe - prevzali sme štafetu / ted' jsou na koni. Na prvý pohlad sa môže zdat', že replika v českom znení je v porovnaní s francúzskou 
verziou expresívnejšia. Po hlbšej analýze a zohladnení kontextu celej vety sa však ukazuje, že zvýšená expresivita na úrovni slovesných tvarov kompenzuje výrazovú stratu na inom mieste vo vete, konkrétne na úrovni označení Les Feujs' a les Noich', pre ktoré boli v českom preklade zvolené neutrálnejšie označenia Židi a Čínani, kedže úplne adekvátny ekvivalent pre francúzsky verlan (pozri d’alej podkapitola 3.2.2.) v slovenčine ani češtine neexistuje. Tento postup hodnotíme pozitívne a je príkladom toho, ako sa v preklade nevyhnutne niečo stráca a následne niečo pridáva s ciel’om zachovat invariant (jadro) originálu (Gromová 2009: 56).

\subsubsection{Preklad príznakových kultúrnych lexém}

Druhý typ analyzovaných jednotiek tvoria lexémy, ktoré sa vyznačujú kultúrnou podmienenostou a zároveň nesú príznak expresivity. Pre ich adekvátny prenos je nevyhnutné, aby mal prekladatel' znalosti o kultúrnom kóde a kontexte a vedel zachovat' expresivitu aj v preklade. V tejto časti si budeme všímat', ako sa s príznakovými jednotkami vysporiadalo slovenské a české znenie. Uvádzané príklady priamo odkazujú na švagrov Davida, Rašida a Chaoa, ktorí majú strávit' Vianoce u svokrovcov.

\section{0:18:29}

FR: Il y aura Lackie Chan et Arafat?

SK: Bude tam aj Jackie Chan a Arafat?

CZ: Jede Lackie Chan a Arafat?

V súvislosti s plánovaným vianočným stretnutím, kde sa má zíst celá rodina, sa David pýta svojej manželky, či prídu aj Chao s Rašidom. Nenazýva ich však ich vlastnými menami, ale v prenesenom význame menami známych osobností čínskej a arabskej kultúry. Sú nimi celosvetovo známy herec a majster bojových umení Jackie Chan a palestínsky vodca Jásir Arafat. Kedže ide o osobnosti známe v slovenskom aj českom kultúrnom priestore, v obidvoch prekladoch sa zvolilo ich zachovanie, čím sa dosiahla štylistická zhoda originálu a prekladu.

\section{$0: 19: 25$}

FR: Y'aura Kadhafi et Enrico Macias?

SK: Aj Kaddáfís Lákobom?

\section{CZ: Bude tam Kaddáfí a Enrico Macias?}

V d’alšej scéne sa Chao pýta svojej manželky, či na stretnutie príde Rašid s Davidom, resp. Kadhafi a Enrico Macias. Rovnako ako v predchádzajúcom prípade, niekdajší líbyjský vodca Muammar al-Kaddáfí bol známy aj v našom a českom kontexte, preto bola v oboch prekladoch táto lexéma zachovaná. Naopak, francúzsky spevák židovského pôvodu Enrico Macias nie je v našom kultúrnom kontexte až taký známy, pričom sa uplatnili rozdielne postupy pri jeho transfere. $\mathrm{V}$ českom preklade došlo k prenosu tejto lexémy, zatial' čo v slovenskom preklade sa nahradila odkazom na ovela známejšiu postavu židovského národa, Jákoba - praotca izraelského národa. Tento postup hodnotíme pozitívne, pretože zaistuje štylisticky adekvátny preklad, ktorý je pre čitatel’a zrozumitel'- 
nejší a prispieva k tomu, že obe kultúrne lexémy sú približne na rovnakej úrovni, pokial’ ide o ich zrozumitel'nost' pre cielového recipienta.

\section{$0: 19: 23$}

FR: Me dit pas qu'il y aura Bruce Lee et Popeck?

SK: Bruce Willis aj s rákosníkom?

CZ: Bruce Lee a Kohen taky?

Posledným z trojice je Rašid, ktorý svojich švagrov nazýva Bruce Leem a Popeckom. Opät’ sa stretávame s jednou známou (Bruce Lee, majster bojových umení ćínskeho pôvodu) a jednou, v našom kultúrnom priestore neznámou lexémou (Popeck - francúzsky komik židovského pôvodu). Pozitívne hodnotíme stratégiu v českom znení, v ktorom sa ponechala v preklade narážka na Bruce Leeho, zatial' čo referencia na Popecka bola nahradená známejšou referenciou odkazujúcou na Kohena (kňaza v židovskom náboženstve), čím je expresívna hodnota v preklade zachovaná. V slovenskom preklade sme zaznamenali prítomnost' lexémy Bruce Willis (známy americký herec). Na prvý pohlad sa môže zdat', že ide o významový posun (Bruce Lee vs. Bruce Willis). Jeho použitie v súvislosti s Davidom by však mohlo byt' odôvodnené tým, že David sa v predchádzajúcej scéne filmu chváli, že ovláda bojové umenia. Avšak aj v tomto prípade sa stráca odkaz na kultúrnu príslušnost' (židovstvo). Chao je následne nazvaný rákosníkom. Ide o etnofaulizmus, výraz, ktorý označuje príslušníkov ázijskej etnickej skupiny, je však generalizujúci a stráca sa tak jedinečnost’ pomenovania prítomná v origináli. Ďalšie vysvetlenie, ktoré prichádza do úvahy, je, že v slovenskom preklade došlo k výmene poradia týchto lexém, t. j. rákosník ako substitúcia Bruce Leea (čínsky pôvod) a Bruce Willis ako substitúcia Popecka, v tomto prípade však nie je evidentný vztah medzi Bruce Willisom a židovskou kultúrou.

\section{1:06:26}

FR: Sauf qu'il y a un Feuj et un Noich qui viennent gratter le business des Musulmans...

SK: Ale ked'sa Žid s Čínanom začnú montovat' Arabom do kšeftov...

CZ: Jenže když se Či i-čong a Moše začnou plést do kšeftů muslimům...

Posledná ukážka príznakových kultúrnych lexém v rámci tejto kapitoly súvisí s používaním slovotvorného postupu francúzskeho jazyka, tzv. verlan, ktorý spočíva v prehodení poradia slabík slova. David a Chao sú vo filme viackrát nazvaní un Feuj (Juif) a un Noich (Chinois), pričom oba výrazy majú silný expresívny náboj, v niektorých kontextoch môžu vyznievat’ až pejoratívne. V českom preklade bolo použité zástupné označenie pre expresívne výrazy označujúce Číňana a Žida - Či-čong a Moše, pričom presnejšia by bola pravdepodobne substitúcia výrazu Noich označením šikmooký. V slovenskom preklade sa expresívny charakter zoslabuje, resp. úplne stráca, pretože David a Chao sú nazvaní len neutrálnymi výrazmi Žid a Číňan. Vhodnejším riešením by mohli byt’ už spomenuté výrazy rákosník a Jákob, ktorými by sa výrazová hodnota na základe danej substitúcie viac-menej zachovala. Výraz Jákob však možno chápat' len ako situačné riešenie, vhodnejším by mohol byt' výraz židák. 


\subsubsection{Nejasnosti a nepresnosti v preklade}

V nasledujúcej časti príspevku by sme chceli upozornit’ na niektoré nejasnosti v slovenskom a českom znení, ktoré sme si pri analýze všimli a ktoré môžu českým a slovenským divákom st’ažit’ recepciu daného filmu.

$1: 02: 46$

FR:

- Le vieux a fait un scandale car ils nont pas voulu le surclasser.

- Pourquoi ? Il avait pris un billet en business?

- Non, mais la dernière fois on l'a surclassé par erreur et maintenant il veut à chaque fois.

SK:

- Vyrobil scénu, lebo ho nedali do prvej triedy.

- Mal tam kúpenú letenku?

- Nie, raz mu omylom vyhoveli a odteraz na tom vždy trvá.

$\mathrm{CZ}$ :

- Nedostal šampus, tak ztropil scénu.

- Mèl letenku první tř́dou?

- Ne, prostě se normálně spletli. Ted' na tom trvá.

Uvedená ukážka pochádza z časti filmu, ked'Charlesova rodina prichádza z Abidjanu do Francúzska, aby sa zúčastnila na jeho svadbe. Dialóg odznel na jednom z parížskych letísk medzi Charlesom a jeho sestrou Vivienne a je reakciou na správanie Charlesovho otca, ktorý vystúpil z lietadla rozhorčený zo služieb na palube lietadla Air France. Slovenská verzia je verným a viac-menej doslovným prekladom z francúzštiny, zatial' čo v českej verzii sa tento dialóg prekladá vol’nejšie. Používa sa výraz šampus ako referencia na business, resp. prvú cestovnú triedu, v rámci dialógu sa však akoby strácala následná logická súvislost’ s dalšími dvoma replikami.

$0: 10: 33$

FR: Beaucoup mieux. Odile est une fille brillante.

SK: Má všetkých pät’p.

CZ: Tak chytrá holka a skončí s vyžírkou.

Druhá ukážka je výňatok z rozhovoru medzi Marie a Claudom, ktorí hodnotia výber manželov svojich dcér. O všetkých svojich dcérach majú samozrejme velmi vysokú mienku, no ani s jedným švagrom nie sú úplne spokojní. V tejto ukážke hovoria o Odile ako o fille brillante. V slovenskej verzii bol zvolený výraz mat’ všetkých pät’ $p^{6}$, ktorý sa chápe vo význame byt dokonalý, t. j. mat všetky požadované vlastnosti. Z hladiska významovej roviny zostáva v preklade zachované významové jadro, ide však o výraz, ktorý sa v súčasnosti v hovorenej reči vel'mi nepoužíva a najmä u mladšej generácie divákov by mohol predstavovat' problém pre pochopenie. Navrhovali by sme preto skôr doslovný preklad Také šikovné dievča. Táto stratégia je prítomná aj v českej verzii - Tak chytrá holka. V čes-

6 Pekná, poctivá, pokorná, pobožná a pracovitá. 
kom preklade je navyše podčiarknutá skutočnost', že Odile „mala na viac“ expresívnou lexémou vyžirka, ktorá sa používa na označenie sebeckého človeka, ktorý sa priživuje na ostatných. Použitím tejto expresívnej lexémy sa český preklad výrazovo zosilňuje, pričom v slovenskom preklade je táto čast úplne vynechaná.

\section{$0: 51: 55$}

FR: Ça fait bizarre un Noir dans un Feydeau.

SK: Čudné. Černoch vo Feydeauovi.

CZ: Černoch ve Feydeauovi vypadá divně.

Túto ukážku sme vybrali z dôvodu, že v prekladatelskej koncepcii sa odrazila absencia zohladnenia skúsenostného komplexu diváka. Odkazuje sa v nej totiž na francúzskeho spisovatela a dramatika Georgea Feydeaua. Možno však predpokladat', že nefrankofónny divák, ktorý nie je velmi dobre oboznámený s francúzskou kultúrou a divadlom, sa $\mathrm{s}$ menom tohto dramatika nestretol. Navrhli by sme preto $\mathrm{v}$ preklade použit vysvetlenie pomocou vnútornej vysvetlivky zakomponovanej do textu repliky - Černoch $\mathrm{v}$ hre od Feydeaua. Hoci v dabingu ako takom je pridávanie textu do repliky problematické, v tomto prípade ide o jednoslabičné slovo, pričom celkový počet slabík v replike sa nemení. Ide navyše o repliku, ktorá je vyslovená pomerne rýchlo a divákovi by bez vysvetlivky mohol jej význam lahko uniknút.

\section{$1: 26: 20$}

FR: Enfin moi, je dis ça jen sais rien, c'est ce quion ma raconté!

SK: Hoci o ženách toho vela neviem, všakže?

CZ: Osobní zkušenost nemám, ale ř́ká se to mezi ženichy.

Posledná vybraná replika pochádza zo záveru filmu a jej autorom je mladý charizmatický kňaz, ktorý má Charlesa a Lauru zosobášit. Kedže nevesta stále nechodí, kňaz sa Charlesa snaží povzbudit', že pekné ženy vždy meškajú, ale že nakoniec vždy prídu. $\mathrm{Na}$ záver dodáva, že on sám toho o ženách vela nevie, ale že to počul od iných. $V$ češtine nastáva $\mathrm{z}$ hladiska štylistickej roviny nivelizácia, pričom bol zvolený explicitný preklad ale říká se to mezi ženichy. Možným variantom by mohlo byt aj skrátené riešenie ale ř́ḱá se to ( $\mathrm{v}$ prípade, ak nebolo treba repliku $\mathrm{z}$ dôvodu lepšej časovej adekvátnosti predížit). $\mathrm{V}$ slovenčine došlo k redukcii tejto druhej časti repliky len na časticu všakže. V porovnaní $\mathrm{s}$ originálom však slovenský preklad vyznieva $\mathrm{v}$ konečnom dôsledku a $\mathrm{v}$ danom kontexte negatívne, pričom ide o posun spôsobený samotným tónom repliky.

\section{Závery}

V príspevku sme sa venovali konfrontačno-komparatívnej analýze vybraných hovorových a expresívnych jazykových jednotiek francúzskeho audiovizuálneho diela Quest-ce quion a fait au Bon Dieu? vzhladom na ich transfer v českom a slovenskom dabingovom znení. Na základe analýzy vybraných ukážok môžeme konštatovat, že v českom preklade diela sa tendencia adekvátnejšieho zachovávania výrazovej zhody pri preklade výrazo- 
vých osobitostí originálu ukazuje častejšie (resp. sa na niektorých miestach uplatňuje výrazové zosilnenie). Túto skutočnost̉ možno v českom audiovizuálnom preklade odôvodnit tendenciou využívat’ obecnú češtinu, ktorá zahŕňa nespisovné, expresívne lexikálne jednotky. Na druhej strane, v slovenskom preklade dochádza častejšie k výrazovému zoslabovaniu (napr. aj úplný zánik expresivity francúzskeho verlanu v preklade), čím sa v konečnom dôsledku stráca dôležitý aspekt charakteru postáv. Dané výrazové zoslabovanie možno sčasti odôvodnit faktorom zohladňovania prijímajúcej kultúry, t. j. istou mierou štandardizácie jazyka originálneho znenia v slovenčine, ale domnievame sa, že v prípade analyzovaného filmu sú hovorovost’ a expresivita $\mathrm{z}$ hl'adiska charakterov postáv zásadné a mali by byt’ zachované vo väčšej miere. Je však otázne, či uvedené príklady zoslabovania vyplývajú sčasti aj zo samotného idiolektu prekladatelky, alebo či vyplývajú najmä z tendencie vyhýbat’ sa subštandardným jazykovým prostriedkom v snahe zachovat spisovnú normu.

Na záver by sme chceli už len vyzdvihnút', že vzhladom na náročnost̉ prekladu skúmaného diela, nedošlo aj napriek niektorým identifikovaným nejasnostiam v slovenskom ani v českom preklade k žiadnemu zásadnému významovému posunu.

\section{LITERATÚRA}

Díaz-Cintas, Jorge - Remael, Aline (2007) Audiovisual Translation: Subtitling, Manchester: St. Jerome Publishing.

Gromová, Edita (2009) Úvod do translatológie, Nitra: Univerzita Konštantína Filozofa.

Krčmová, Marie (2017) 'Obecná čeština', in Petr Karlík - Marek Nekula - Jana Pleskalová (eds.) CzechEncy - Nový encyklopedický slovník češtiny. [online]. https://www.czechency.org/slovnik/OBECNÁ ČEŠTINA (access: 30. 11.2018).

Paulínyová, Lucia (2017) Z papiera na obraz - Proces tvorby audiovizuálneho prekladu, Bratislava: Univerzita Komenského.

Popovič, Anton (1983) Originál-Preklad: Interpretačná terminológia, Bratislava: Tatran.

Pošta, Miroslav (2011) Titulkujeme profesionálne, Praha: Apostrof.

Štícha, František et al. (2013) Akademická gramatika spisovné češtiny, Praha: Academia.

Zahorák, Andrej (2018) Špecifiká prekladu audiovizuálnych textov pre detského diváka, Rigorózna práca. Nitra: Univerzita Konštantína Filozofa v Nitre.

\section{Materiálová báza}

Qu'est-ce qu'on a fait au Bon Dieu? 2014. DVD.

Co jsme komu udělali? 2015. DVD.

Čo sme komu urobili? 2016. Vysielané na RTVS Jednotka.

\section{Internetové zdroje}

Slov-Lex, Právny a informačný portál, https://www.slov-lex.sk/pravne-predpisy/SK/ZZ/2000/308 (access: 9. 12. 2019). 


\section{RESUME}

Larticle a pour but de procéder à une comparaison contrastive des versions française, tchèque et slovaque de l'œuvre audiovisuelle d’origine française intitulée Qu'est-ce qu’on a fait au Bon Dieu ? L'article débute par une présentation de l'œuvre analysée et une délimitation du cadre théorique, notamment la définition de la traduction audiovisuelle comme un genre spécifique de la traduction, ainsi que les particularités du rôle du traducteur dans le cadre du doublage. Laspect pratique de l'article consiste en une analyse des unités expressives, du vocabulaire familier et des expressions culturelles et de leur transfert dans les versions traduites du point de vue de leur expressivité.

\section{Mgr. Jana Ukušová}

Katedra translatológie, Filozofická fakulta, Univerzita Konštantína Filozofa v Nitre jana.ukusova@gmail.com 